DOI: https://doi.org/10.47405/mjssh.v5i11.531

\begin{tabular}{|c|c|}
\hline 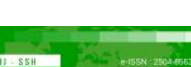 & Malaysian Journal of Social Sciences and Humanities (MJSSH) \\
\hline Malaysian Journal of & Volume 5, Issue 11, November 2020 \\
\hline (MJ-ssH) & e-ISSN : 2504-8562 \\
\hline & $\begin{array}{l}\text { Journal home page: } \\
\text { www.msocialsciences.com }\end{array}$ \\
\hline
\end{tabular}

\title{
Constructing the Palestinian Nation Via Narration and Attachment in Mornings in Jenin: A Postcolonial Perspective
}

\author{
Majeed Abjel Ferhood ${ }^{1}$, Lajiman Janoory ${ }^{1}$ \\ ${ }^{1}$ Department of English Language and Literature, Faculty of Languages and Communication, \\ Universiti Pendidikan Sultan Idris (UPSI), Malaysia \\ Correspondence: Majeed Abjel Ferhood (majeedferhood11@gmail.com)
}

\begin{abstract}
This article aims at carving the Palestinian nation in the global map via narration. As an artistic genre, Susan Abulhawa's Mornings in Jenin (2010) is a reaction against the methodical Jewish plan that powerfully strives to erase the Palestinians and their state from the universal map in the aftermath the turning event of the 1948 catastrophe. The article traces actions and behaviours of the immigrated Palestinian characters whose minds, souls and bodies have a strong attachment to their native homeland. Based on the notable post-colonial theorist Homi Bhabha's theory of nation, I do a careful reading of the Susan Abulhawa's novel within the theoretical framework of postcolonial criticism. Homi Bhabha encourages the people of the colonized nations including the Palestinians to restore their stolen homelands by narration and a permanent reminiscence. The study concludes that the Palestinians will not forget their case forever. The continuation of narrating the Palestinian story will doubtless abort the colonialism.
\end{abstract}

Keywords: postcolonial discourse, nationhood, narration, imagination, belonging

\section{Introduction}

Bhabha's theory regarding the notion of the nationhood mainly concerns narratives, as they form and build a national identity of colonized peoples. The nation is reconstituted via its language and culture. He contends the importance of the act of recitation, narrative, myths, literary language, folk beliefs that grant those colonized people a sense of national belonging in their day-to-day lives. In Bhabha's thought, the nation is explored as an imagined construction which allows the colonized people to represent themselves as united communities. To put it simply, Bhabha believes that nations have to be recited and discovered. He motivates and encourages the people to handle the concept of the nation as they imagine and write because nations are similar to narratives; their origins are realized in the eye of the mind.

Bhabha's idea of the nationhood is as a multi-faceted construction. He also contends the significance of carving the nation via what he calls a "counter-narrative" (p.300). He sees this kind of narrative is made via the ability of response to collecting national memory. To put it in Bhabha's words, they are-Counter-narratives of the nation that continually evoke and erase its totalizing boundaries-both actual and conceptual — disturb those ideological manoeuvres"(1990, p.300) through which imagined communities are granted essentialist identities. By applying these ideas onto the Palestinian novelists, it becomes clear that their sense of nation is, to a large extent, formed and built through yearning, 
memory and imagination. Such postcolonial themes play a pivotal role in exploring Palestinian literary works and creating and building a nation as an imagined community in representing Palestine.

\section{Methodology}

The basic data created this article is literary novelistic genre named Mornings in Jenin (2010) by a Palestinian novelist Susan Abulhawa. The novel was selected on the basis of embodying postcolonial issues. Textual analysis is employed to written narratives such as the novelistic genre and short story (McQuillan,2000). As a textual analysis of the contemporary Palestinian novel, especially in its postcolonial phase that revolves around postcolonial themes such nationhood, memory and yearning, this article regarded the postcolonial theory as suitable and crucial to analyse such themes. In order to do so, theories of nationhood and narration by the following prominent postcolonial scholar Homi Bhabha were selected to discuss the mentioned themes in novel.

\section{Discussion and Result}

Before we go on a long journey towards discussing the intended idea, it is necessary to indicate that Susan Abulhawa who is a diasporic Palestinian novelist born in Kuwait, lived in Jerusalem and eventually, at thirteen years of age, lives in the United States in America. Her diasporic identity is formulated by such contexts. In an interview, Susan Abulhawa states "I did not grow up around my parents very much...My childhood was quite unstable and unrooted, owing mostly to family circumstances. I have mostly felt my way through life"(Snaije, 2012, p.5). The writer clearly tells us about her forced uprooting far away from the native homeland. However, she has resisted these hard circumstances through employing postcolonial issues such ongoining imagination, permanent memory, yearning and narration of the homeland.

Abulhawa is accounted among the national Palestinian voices whose novel Mornings in Jenin (2010) is filled with connotations and passages of the revolutionary national voice against colonial discourse. AlJahdali (2014) points out that Susan Abulhawa's Mornings in Jenin draws ways of confronting and reconstructing geographical region and the history of Palestine through the return journey of the exile to Palestine. Moreover, AlJahdali adds that the narrative also explores how walking and returning have a meaningful connotation in the mythic constructing of the Zionist discourse and how Palestinians show their potency to resist the domination of colonial narratives. This is something that is, to a great extent, similar to Bhabha's thought of the theme of nationhood. Indeed, the above statements explore that Abulhawa's Mornings in Jenin strives to counter the Zionist discourse which attempts distorting Palestinian history. This discourse endeavours at reminding to the world and the diasporic Palestinians of the right of return and catching their national identity through their love for their country of origin and bond to their land and its landscape.

Mornings in Jenin, as a historical document, examines the most significant incidents of the history of Palestinians that pertains to the outstanding Israeli-Palestinian struggle which emerges from the 1948 catastrophe, the 1967 event, the 1982 massacres of Shatila and Sabra to 2002. However, in a clever and target way, Abulhawa sends us back some years to the pre-occupation period. The goal is to compare the years of the ordinary life of Palestinian people in their homeland that preceded the establishment of the Israeli state with those years when they suffer and experience in exile. Thus, before we proceed to explore the events of the novel within the frame of this study, it will be of benefit to mention few events in the novel to describe the past days of the pre-Nakba era in Ein Hod village when Palestinian families used to live a free and stable life on their native lands. The novelist starts the novel with an exploration of four generations of a family called Abulhija living in their village, Ein Hod in Palestine. Before the Israeli invasion of Palestine, the writer narrates how Palestinians' lifestyle, their harmonious and peaceful kinship relations, attachment to their native land and bonds of intimacy between individuals of the Palestinian family are very strong. Indeed, "[a]ttachment to God, land, and family was the core of [the Palestinians] being and that is what they defended and sought to keep"(Mornings in Jenin, p.28). Attachment to land is employed in the novel through family individuals of Abulhija. 
For instance, the father of the family, Yehya forbade his son Hassan to complete his study as he tells him "[b]ooks will do nothing but come between you and the land"(Mornings in Jenin, p.16). The reason given is Hassan will be busy from the great task of farming and serving the land. Such commitment is the major concern for the peasants who have preserved the native land from one generation to another. After many years, Yehya excuses to his son Hassan for rejecting to attain his educational purposes and ambitions. Yehya's attitude exposes the excessive love for his native land, which spreads in his blood. Throughout history, the population of Ein Hod are fighters who have protected their native homeland from many colonial invaders. They "want only to live on their land as they always had. For they had endured many masters-Romans, Byzantines, Crusades, Ottomans, British-and nationalism was inconsequential"(Mornings in Jenin, p. 28).

The novelist introduces Yehya Abualhja as an aged man whose main goal both before and after colonialism is a relationship with the native land and its landscape. This is to say that in Abulhawa's world the Palestinians are capable of attaching to their native land even if they live in diaspora environments. This is exactly what taken place to Yehya when he was extirpated along with his family members from their hometown in Ein Hod. Expelled from his native land in the village because of the Zionist invasion and their violent practices of dispossession and forced expulsion, Yehya lives as a refugee far away from his native land in camps in Jenin. He dislikes being a refugee because he is not used to living as a refugee in Jenin and he often looked forward to returning to his village. Due to a magical and wonderful nature of Ein Hod and its spiritual effect, Yehya unconsciously returned to Ein Hod in secret and he remained there for many weeks. He says, "that terrain is in my blood ...I know every tree and every bird. The soldiers do not"(Mornings in Jenin, p.40). There is a mental relation between Yeyha and his village. He has grown up on it and worked and loved it. Furthermore, the novelist depicts Yehya's bond to his country of origin as similar to his relation to paradise. Yehya's nostalgia and his return to the village are explored in the following quotation, "he came back from his sixteen days in the paradise of realized nostalgia"(41).

In fact, "[t]he events of the Palestinian expulsion in 1948 have rendered the old family home a place of painful memory and a symbol of what has been taken"(Sa' di \& Abu-Lughod, 2007, p. 2). Yehya visited his native homeland for a second time. Unfortunately, this was the last trip of his village as the journey to Ein Hod costs Yehya his life. Abulhawa does not inform us about the reason for his death; however, some people believed that Yehya's death is due to the tragedy of being expelled from his homeland. The people find his dead body in his village with some olives and figs that he normally carried in his pockets in his hand as a sign of his hope of returning to the homeland. Yehya has an unshakable sense of attachment. For Yehya, it seems that manifestations of rural life in Palestine mean a lot and its natural landscapes and air permeate his mind and soul. As a villager, Yehya yearned for the past years in the village whose olive trees mean for him belonging and rootedness. Yehya who finds himself in refugee camps has a powerful attachment with his lost homeland and his identity. This means that he always protects his sense of belonging to his land and he must come back regardless of the negative effects and consequences. A place, thus, is a very urgent necessity to the constructing of national and personal identity.

The complexity in building a sequence of history is obviously explored in the Palestinian inclination and urgency to ignore the present by trading it for a past, which is fixed, a past ruled by rituals and images. For establishing the alternative historical story, the need for three branches is urgent: the permanent remembrance of a lost paradise, the mourn for the present, and depiction of the intended return. In this inclination, the historical case of Palestinian features other histories of displacement and exile, in which quotidian existence is experienced through the permanent permeation of yearning "for the lost nature-and-nation unity, and for the utopian homeland that remains untainted by contemporary affairs" (Gertz \& Khleifi, 2008,p. 2-3).

Yehya is not the only refugee who cannot harmonize with the new wretched environment in the refugee camps of Jenin. As the narrative progresses, we also learn that in a refugee camp in Jenin Yehya's son named Hasan and his wife, Dalia gives birth to a new baby named Amal, who was born on July, 1955. She represents the third generation of Abulhija family. Actually, the first person to make Amal realizes truly the relation to her homeland is her father, Hassan whom she calls Baba. At the 
early stage of her adolescence, when Amal was around five years, Amal comes across her father every morning where he reads on the balcony. The father places Amal on his lap and states, "[1]isten to the words I read. They're magical" (Mornings in Jenin, p.51). Even though it is hard for the five-year-old to understand the classic Arabic prose, Amal realizes that "the cadence was mesmerizing, and Baba's voice was a lullaby" (Mornings in Jenin, p.51). The next morning, only prior to dawn, Amal is excited to "once again have a special place in Baba's morning"(Mornings in Jenin, p.51). Again and again, Hassan reads to Amal, and this becomes an integral part of her quotidian routine to contribute in the mornings in Jenin with her Baba.

Furthermore, Amal, at a very early age, has been inculcated by her father Hassan the great magnitude of significance the powerful bond between people and their native land. He teaches her the land "belong to you, as you can belong to it. We come from the land, give our love and labour to her, and she nurtures us in return. When we die, we return to the land. In a way, she owns us. Palestine owns us and we belong to her" (Mornings in Jenin, p.54). The allegiance of and faith in the national cases leads to a firm rejection to abandon to its loss. The novelist introduces natural phenomena as connotations of national belonging. An olive tree called 'The Old Lady' whose age is five hundred years old indicates Palestine herself, the virginal native land that can 't be possessed and dissipated. When Amal called for possessing the tree Hassan illustrates to his daughter that "no one owned Old Lady. This old girl was here before any of us, and she'll be here long after we 're gone"(Mornings in Jenin, p.54). The tree is also a good connotation illustrating the symbolic relationship with the landscape which symbolizes deep rootedness. In this sense, representations of a nation through metaphors are taken as a strong indication through which Palestinian people are being rooted in the native territory and call for national identity and historical rights. Schulz \& Hammer (2014) point out that "[a] representation of a peasant past and an ideology of cultivating the land portray rootedness and belonging to the land"(p.15). Schulz \& Hammer go on to give more instances about how peoples including the Palestinians indicate their rootedness "as a symbol of rootedness, as in the Swedish fir and birch, the Lebanese cedar or the Palestinian olive tree"(p.15). The season of the olive harvest, as recounted in the narrative, is also as an illustration of farming traditions and a mark which employs bonds and connections of the Palestinians with the land.

At the age of 17 and after the death of her parents, Amal becomes orphaned and spent many years in an orphanage In Jerusalem. She forms great friendships through which her sense of belonging is developed. Indeed, later on, Amal nostalgically invokes these previous years when she states "it is true we had no heat to warm our nights... but we had much of the stuff that warmed our souls. We were friends who doubled as mothers, sisters, teachers, providers, and sometimes as blankets" (Mornings in Jenin, p.132). By the same token, Amal describes the manner through which she, along with her colleagues, vanquish the hard difficulties whenever they confront in the orphanage;"[o]ur bond was Palestine. It was a language we dismantled to construct a home "(Mornings in Jenin, p.133).

In the United States of America, Amal desired to imitate Western traditions and, thus, the yearning of return was not a very serious case to her as she points out "[a]nd to be honest, I wanted to be an American. I wanted to pack away my baggage of past and tragedy and try on Amy for size"(Mornings in Jenin, p. 147). However, when Yousef, her brother and her brother's wife, Fatima call her, Amal "thought of little else but to return" (Mornings in Jenin, p.144) to her family members and herself. Her return from America to Palestine, which manifests several times through which the novel, mirrors an act of retracing actions of her national belonging and memories, narrating the ways through which she realizes herself. AlJahdali (2014) points out that "for exiled Palestinians, this return journey becomes a site of production whereby... they connect to traditions and genealogies to produce themselves anew" (p. 225). Similarly, when she comes back to Lebanon to meet her brother, she has the potency to realize and understand an intense feeling of national longing there precisely due to the link that later on reinforces between her and Majid, her brother's friend. However, the real sense of belonging is not fully achieved until she returns accompanying her daughter Sara to Jenin. Thus, for Amal, as the novel recounts us, the homeland is ultimately found in her daughter. 


\section{Conclusion}

This article was an attempt to reconstruct the Palestinian nation via narrating some inquiries and questions of postcolonial themes like yearning, nostalgia, memory, and the strong bond to the land that closely related to the notion of nationhood. Such themes were explored in Susan Abulhawa's Mornings in Jenin. By applying Homi Bhabha's theoretical assumptions of nationhood and narration, the article examined and situated this Palestinian work in the realm of postcolonial literary discourses. In the analytical section, the study has tracked the attitudes and response of Palestinian native characters towards their Palestinian nation. The study also explored the persistent preoccupation of the immigrated Palestinian characters towards Palestine and how they maintained their national identity via narration and persistent memory of their homeland. The article concludes that the Palestinian nation is a location that strongly rebuilds a nation and resists Israeli colonizers who always inscribed the Palestinians as a forgotten people whose land should be raped by force. By adopting Bhabha's notion of nations, the Palestinian characters have been employed to create imagined communities to reverse the colonial dominated discourses.

\section{References}

Abulhawa, S. (2010). Mornings in Jenin: A Novel, USA, New York: Bloomsbury

AlJahdali, S.H. (2014).Venturing into a vanishing space: the chronotope in representing Palestinian postcoloniality. Journal of Postcolonial Writing, 50(2), 216- 229. Doi.org/10.1080/17449855.2014.883180

Bhabha, H. (Ed.). (1990). Nation and Narration. London \& New York: Routledge.

Gertz, N. \& Khleifi, G. (2008). Palestinian Cinema: Landscape, Trauma and Memory: Landscape, Trauma and Memory. Edinburgh, Edinburgh University Press Limited.

McQuillan, M. (Ed). (2000).The Narrative Reader. London \& New York: Routledge Press.

Sa'di, A. H., \& Abu-Lughod, L. (Eds.). (2007). Introduction: The Claims of Memory. In Ahmad H. Sa'di \& Lila Abu-Lughod (Eds.), Nakba: Palestine, 1948, and the claims of memory, (pp.1-24), New York, Chichester, West Sussex, Columbia University Press.

Schulz, H. L. \& Hammer, J. (2005). The Palestinian Diaspora: Formation of identities and politics of homeland. London \& New York, Routledge.

Snaije, O. (2012). The many lives and languages of a Palestinian novel. Middle East. Retrieved from https://publishingperspectives.com/2012/03/the-many-lives-and-languages-of-a-palestiniannovel/.(Accessed $8^{\text {th }}$ October 2019) 